\title{
Pandemics, leadership, and social ethics
}

\author{
Miguel Ángel Escotet ${ }^{1}$
}

Published online: 2 June 2020

(C) UNESCO IBE 2020

\begin{abstract}
This Viewpoint argues that the absence of worldwide social ethics is at the root of our present social, political, and economic crises. More to the point, the current COVID19 pandemic is, in part, a consequence of insufficient scientific research, inappropriate education systems, and globally fragile health structures and human services.
\end{abstract}

Keywords Pandemic $\cdot$ Leadership $\cdot$ Social ethics $\cdot$ Education $\cdot$ Crisis

The COVID-19 pandemic we are facing is, in part, a consequence of insufficient scientific research, inappropriate education systems, and globally fragile health structures and human services. But we invest much more in maintaining political structures and political movements than in any of those areas.

As education professionals, we know that we live in a world in turmoil: a world of collapsing ideas, instant gratification, unfulfilled promises, and crashed ideologies. We experience the forces of change invading our classrooms every day, even as the voices of discontent demand radical reform of all levels of public education, including higher education.

At the same time, we must confront a new dark age in political and social leadership. Gloucester's disturbing words in King Lear are fitting: "Tis the time's plague when madmen lead the blind" (Shakespeare 2015). With some exceptions, many local, national, and global leaders display a surprising disregard for culture and an appalling absence of affective and emotional development. They lack the vision necessary to propel changes and the democratic soul to act in good faith. They demonstrate hopelessly deficient management skills, exude selfishness, lack compassion, and denigrate transparency. They seem to be motivated by power, not by service. Our societies need leaders and visionaries. In the

Miguel Ángel Escotet

miguel.escotet@ieside.edu

1 Intercontinental Higher Education Institute of Business (IESIDE), Av. de Madrid, 60, 36204 Vigo, PO, Spain 
words of Yuval Noah Harari, “So far we don't see anything like the strong global leadership we need" (Harari 2020).

The world is threatened not only by a severe economic crisis but also by natural and man-made disasters - from oil spills to radioactive leaks, from underdeveloped sanitation to climate change. There is also an oppressive feeling that we are losing everything that was reliable, predictable, and able to guide us in solving our problems. Political, economic, and social corruption is increasing. Anger and dissatisfaction create discontent in every corner of the world, as those considered responsible for the crisis we face are condemned as selfish, greedy, unfair, arrogant, and cynical. More than ever, we see firsthand the deleterious consequences of the "I deserve everything" philosophy, practiced with absolute contempt for the people who will suffer its consequences. As ordinary citizens, we know this is not only a public health and economic crisis, regardless of what politicians and economists say. We feel in our bones that this is an ethical crisis, a structural problem that we cannot solve using the same ways of thinking that created it.

After the defeat of Nazism, humanity viscerally rejected the cruel philosophies of hate that provoked the most terrible nightmare of the twentieth century: the extermination of millions of innocents in the name of one Race, one Realm, one Leader. That sense of horror gave rise to a moral revolution: the rights movement, which recognized the civil liberties of women, children, and minorities.

It would be interesting to pinpoint exactly when the memory of the Nazis' crimes began to vanish, dissolving like those midnight nightmares that we are unable (or unwilling) to recall the next morning. In that moment, the stain of innocent blood was erased, and human beings emptied their souls, embracing the new narcissistic philosophies of selfishness and greed. They began to define the "good life" as one driven by the quest for money and power: a life without shame, remorse, gratitude, compassion or goodwill.

In recent years, there have been significant efforts to convince people that altruism, compassion, and tolerance are not virtues at all, but empty words motivated by spiritual snobbery and totalitarian ambition. Growth for the sake of growth has overridden environmental protection. Sympathy for the unfortunate is considered a sign of weakness, which only serves to multiply dependence on the State, leading to a tax burden on hardworking and creative (now redefined as wealth-creating) individuals. We are bombarded with the idea that consumption is happiness, all in the name of freedom. As the Czech poet Czeslaw Milosz said about his life under communism, "we were permitted to shriek in the tongue of dwarfs and demons, but pure and generous words were forbidden” (Milosz 2003).

In view of their consequences, we recognize these ideas as crude intellectual errors defining a narrow world. But the world is not narrow anymore. We, as psychologists and educators, know that new technologies have expanded the horizons of children and adults, and that many possibilities are open for acquiring cognitive abilities. We know that truth is increasingly more difficult to hide, which only underscores the importance of rectitude, fairness, integrity, and the need for critical thinking.

These new technologies allow people to unmask moral hypocrisy and to discover more easily the gap between what is preached and what is practiced. Ethics should be taught as the search for truth, not as the expression of opinions or from the narrow perspective of spiritual snobbery. Ethical behavior cannot be achieved by just adding courses or activities to programs of study. It needs to be embedded in all our educational processes, as a lifelong learning progression.

The times call for a new ethical revolution in education (and society as a whole) that stresses the importance of the human being - not merely as the invisible hands of the marketplace, or as a consumer of goods, or even as an isolated brain, without a heart, without 
a conscience, and without artistic sensibility. We need to educate for ethics and aesthetics, for a commitment to justice and liberty, for the ability to admire the beauty of human creations, and for respecting the planet and its biodiversity. We cannot teach to the test at the expense of teaching to the heart. That type of teaching only values a short-term learning process instead of an attitude of lifelong learning.

Ethical education should be a commitment against cruelty, against intolerance and fanatical moralism. Aesthetic education lets us admire the beauty of human creations, while integrity leads us to understand that people who think, live, and behave differently than us are capable of enriching our lives with marvelous creations in science, technology, and art. We need to teach the language of emotions and how to interact in compassionate and intelligent ways, so we can accept, understand, and manage our feelings and the feelings of people around us. We need to be more attached to knowledge than to certificates and diplomas. In the short term, we will need to combine face-to-face education with distant individualized learning.

We need education for liberty and the responsibilities it implies. Liberty without responsibility is a license to do anything without ethical considerations, to forget justice and the rights of others, and to receive without gratitude because we deserve it all. It is to live under the false impression that life has only rewards, no consequences or punishments. Education for liberty is education for making decisions based on ethical reflection-on how those decisions will affect our own lives, the life of our fellow humans, and the life of the planet.

Ethical education should embrace the place of freedom in our lives. Education without liberty is indoctrination; it exercises authority by intimidation and not by inspiration. Education for freedom is education for accepting oneself, for searching, for experimenting, for doubting, for making mistakes, for expressing feelings without fear of being subject to punishment or ridicule. We need freedom to be able to question authority, to speak without coercion, and to challenge the dogmas of the times. Bear in mind Voltaire's warning: "anyone who has the power to make you believe absurdities has the power to make you commit injustices" (Torrey 1961, pp. 277-278).

Many wars have relied on propaganda making people believe absurdities. The bad news is that we now live in a more dangerous world than the world of Voltaire, not least because we have weapons of mass destruction that can fall into the hands of anyone. The good news is that we also have powerful communication technologies that can be used to avoid conflicts and to help good leaders, so that with strong determination they may spread their messages of tolerance.

To those who say this sounds too idealistic, too difficult, and too expensive, I would say that wars, pandemics, and destruction are more expensive. The new generation lives in a world invaded by information, so they need creativity to replace, not repeat, the mistakes of past generations. They will need sensibility to appreciate and protect the immortal creations of the human talent, and most of all they will need ethics to guide their decisions. They will have access to information not tainted by ideologies, governments, or economic or political interests, but they will need the wisdom to separate the wheat from the chaff. They will need the power of imagination to construct new models and new tools to replace a world in decline. They are going to live in a real global village, where human interactions will be more diverse and wide-ranging despite social distance. For all these reasons and more, we need an education for the emotions, to avoid unnecessary conflicts and create an authentic human family.

In a world invaded by novelty and glaring technologies, human beings need the moments of peace and introspection that only art and the proximity of nature can offer. The 
aim of the new education will be to liberate the mind from the idea that we are somehow separated from nature and from the rest of humanity. "This delusion", to quote Albert Einstein, "is a kind of prison for us, restricting us to our personal desires and to affection for a few persons nearest to us. Our task must be to free ourselves from this prison by widening our circle of compassion to embrace all living creatures and the whole of nature in its beauty" (Sullivan 1972).

\section{References}

Harari, Y. (2020). Yuval Noah Harari: "Every crisis is also an opportunity". UNESCO Courier. https:// en.unesco.org/courier/news-views-online/yuval-noah-harari-every-crisis-also-opportunity.

Miłosz, C. (2003). New and collected poems (1931-2002). Trans. Robert Hass and Czeslaw Milosz. New York, NY: HarperCollins Publishers.

Shakespeare, W. (2015 [1605]). King Lear. New York, NY: Simon \& Schuster.

Sullivan, W. (1972). The Einstein papers: A man of many parts. The New York Times. https://www.nytim es.com/1972/03/29/archives/the-einstein-papers-a-man-of-many-parts-the-einstein-papers-man-of. html.

Torrey, N. (1961). Les philosophes: The philosophers of the Enlightenment and modern democracy. New York, NY: Capricorn Books.

Publisher's Note Springer Nature remains neutral with regard to jurisdictional claims in published maps and institutional affiliations.

Miguel Ángel Escotet (Spain, United States) is professor emeritus and former dean of the University of Texas System, as well as a former Frost professor at Florida International University. He was executive director of The Interamerican University Council for Economic and Social Development and secretary general of the Organization of Iberoamerican States for Education, Science and Culture (OEI). Presently he is rector of The Intercontinental Higher Education Institute of Business (IESIDE) and the UNESCO Honorary Chair on the History and Future of the University. More information at www.miguelescotet.com. 